\title{
MODEL KINERJA FINANSIAL PEMERINTAH DAERAH MELALUI ASET DAN PENDAPATAN ASLI DAERAH
}

\author{
Kun Ismawati ${ }^{1}$ \\ 1) Universitas Surakarta
}

\begin{abstract}
The research aimed to explore financial performance's model of the Karanganyar Regency Regional Government. This research tested the impact of size, richness, leverage, and capital expenditure on the financial performance of the Karanganyar Regency Regional Government. Research data were 8 (eight) periods of financial statements. Hypotheses analyzed with multiple linear regression. Analysis results showed that size and richness have a significant positive impact on the financial performance of Karanganyar Regency Regional Government; while leverage and capital expenditure have a significant negative impact on the financial performance of the Karanganyar Regional Government. Those results illustrates that greater size and richness will increase the financial performance; on the contrary, the greater leverage and capital expenditure will decrease the financial performance. The model explored is $\mathrm{Y}=-75.79+109.039 \mathrm{X}_{1}+3.754 \mathrm{X}_{2}$ $-0.582 \mathrm{X}_{3}-0.231 \mathrm{X}_{4}$.
\end{abstract}

$\begin{array}{ll}\text { Keywords } & \text { : size; richness; leverage; capital expenditure; regional government } \\ & \text { financial performance } \\ \text { Correspondence to } & : \text { kun.ismawati@gmail.com }\end{array}$

\begin{abstract}
ABSTRAK
Penelitian ini bertujuan menggali model kinerja finansial Pemerintah Daerah Kabupaten Karanganyar. Penelitian ini menguji pengaruh ukuran, kekayaan, leverage, dan belanja modal pada kinerja finansial Pemerintah Daerah Kabupaten Karanganyar. Data penelitian ini adalah 8 (delapan) periode laporan keuangan. Hipotesis dianalisis dengan regresi linear berganda. Hasil analisis menunjukkan bahwa ukuran dan kekayaan memiliki dampak positif signifikan pada kinerja finansial Pemerintah Daerah Kabupaten Karanganyar; sedangkan leverage dan belanja modal memiliki dampak negatif signifikan terhadap kinerja finansial pada Pemerintah Daerah Kabupaten Karanganyar. Hasil-hasil tersebut menggambarkan bahwa makin besar ukuran dan kekayaan akan meningkatkan kinerja finansial; sebaliknya, makin besar leverage dan belanja modal akan menurunkan kinerja finansial. Model yang tergali adalah: $\mathrm{Y}=-75.79+109.039 \mathrm{X}_{1}+3.754 \mathrm{X}_{2}-$ $0.582 \mathrm{X}_{3}-0.231 \mathrm{X}_{4}$
\end{abstract}

Kata kunci : : ukuran; kekayaan; leverage; belanja modal; kinerja finansial pemerintah daerah

\section{Riwayat Artikel:}

Received : 14 Desember 2020

Revised : 18 Januari 2021

Accepted: 22 Januari 2021 


\section{PENDAHULUAN}

Permasalahan dalam pemerataan hasil pembangunan menuntut diberlakukannya otonomi daerah, dipertegas dalam UU No. 23/ 2014 mengenai Pemerintahan Daerah, yang menyatakan bahwa otonomi daerah merupakan wewenang mengurus kepentingan masyarakat secara mandiri di daerah. Otonomi mensyaratkan keuangan berimbang, adil, sesuai proporsi, serta adanya transparansi (Hasan, 2013) sehingga pengelolaan keuangan dalam pelaksanaan otonomi daerah menjadi hal utama yang harus menjadi perhatian pemerintah daerah (Sijabat et al. 2014, 23); sebagai acuan, berbagai indikator bahkan telah dikembangkan oleh pemerintah daerah di Irlandia untuk mampu menilai kinerja keuangan pemerintah daerah mereka, sehingga dapat mendeteksi dini terjadinya kesulitan keuangan di daerah (Turley et al. 2015).

Pelaksanaan pengelolaan keuangan terkait dengan pengukuran kinerja finansial dalam rangka menilai akuntabilitas pemerintah daerah, yang terdapat pada laporan keuangan dan tersaji dalam neraca, realisasi anggaran, dan kinerja finansial yang bermanfaat bagi pengambilan kebijakan (Puspitasari 2013). Manajemen keuangan daerah digunakan sebagai alat pengelolaan keuangan di daerah (Halim 2012).

Keberhasilan otonomi daerah salah satunya ditunjang oleh tersedianya informasi yang memadai dalam kebutuhan penilaian kinerja finansial pemerintah daerah (Fitriani et al. 2014). Salah satu alat pengukuran untuk mengetahui kapabilitas daerah dalam melaksanakan otonomi daerah adalah kinerja keuangan (Halim, 2016). Ada dua unsur kinerja finansial yang dibandingkan antara sebelum dan setelah era otonomi daerah yakni wewenang pembiayaan daerah dan pengelolaan keuangan daerah (Mardiasmo, 2016).

Teori agensi menjelaskan hubungan agen dan principal agar agen dapat menjalankan kegiatan seperti yang diharapkan principal. Aplikasi teori ini di public sector digambarkan bahwa terdapat hubungan keagenan antara rakyat dengan pemerintah, atau antara pusat dengan daerah. Pemerintah daerah bertanggungjawab pada pusat yang telah memberi mandat, selain juga kepada masyarakat untuk membuat mereka sejahtera (Halim \& Abdullah, 2015).

Berbagai hal dianggap berpengaruh pada kinerja finansial pemerintah daerah. Minarsih (2015) menyatakan ukuran pemerintah daerah (size) salah satu faktornya. Tuntutan rakyat akan lebih tinggi pada pemerintah yang lebih banyak dan lebih luas dalam melayani mereka. Layanan pemerintah daerah kepada masyarakat dalam jumlah yang makin banyak dianggap melibatkan resources yang lebih besar terutama pelibatan keuangan daerahnya, sehingga ukuran pemerintah dianggap memiliki pengaruh pada kinerja keuangan pemerintah daerah.

Ukuran pemerintah daerah diproksikan dengan total aset, dianggap memiliki dampak positif dan signifikan pada kinerja finansial pemerintah daerah (Sari, 2016), namun hasil penelitian lain menyatakan berpengaruh negatif signifikan (Sari \& Mustanda, 2019; Mulyani \& Wibowo, 2017). Hasil yang berlawanan dinyatakan oleh Harnanto (2017) serta Febrianto (2018) bahwa ukuran pemerintah daerah tidak memiliki pengaruh pada kinerja finansial pemerintah daerah.

$H_{1}$ : diduga ukuran memiliki pengaruh signifikan terhadap kinerja finansial Pemerintah Daerah Kabupaten Karanganyar.

Strategi investor bila berada pada pasar yang dinamis biasanya dilakukan dengan mengoptimalkan kekayaan. Strategi ini yang dianggap paling efektif (Lo, et al, 2017). Kekayaan (richness) dalam penelitian ini diproksikan dengan Pendapatan Asli Daerah (PAD); sesuai dengan UU No. 23/ 2014 mengenai pendapatan, belanja, dan pembiayaan yang menyatakan bahwa PAD dapat meliputi pajak di daerah, retribusi daerah, dan hasil kekayaan daerah yang dikelola.

Beberapa penelitian menyimpulkan bahwa PAD berpengaruh positif signifikan pada kinerja finansial pemerintah daerah (Sari, 2016, Sari \& Mustanda, 2019; Leki, et 
al. 2018; Atmaja, et al, 2015, serta Andirfa, et al 2016). Hasil berbeda dari penelitian Mulyani \& Wibowo (2017) yang menyatakan bahwa pengaruhnya negatif signifikan. Riset Febrianto (2018) menunjukkan PAD justru dianggap tidak memiliki dampak terhadap kinerja finansial pemerintah daerah.

$\mathrm{H}_{2}$ : diduga kekayaan memiliki pengaruh signifikan pada kinerja Pemerintah Daerah Kabupaten Karanganyar.

Leverage menggambarkan bagaimana aset dibiayai dengan hutang dibanding menggunakan modal intern. Investasi dianggap berisiko tinggi bila leverage makin tinggi, begitu pula sebaliknya. Besarnya leverage menunjukkan buruknya kinerja disebabkan ketergantungan besar pada external resurces (Syamsuddin, 2016). Perwitasari, 2010; Minarsih, 2015; dan Sari, 2016 menyatakan bahwa kinerja dipengaruhi oleh leverage.

$H_{3}$ : diduga leverage berpengaruh signifikan pada kinerja finansial Pemerintah Daerah di Kabupaten Karanganyar.

Kinerja keuangan daerah juga dipengaruhi belanja modal (Mulyani, et al, 2017). Belanja modal juga memiliki pengaruh positif tidak signifikan pada kinerja keuangan pemerintah daerah (Leki, et al, 2018; Andirfa, et al, 2016; Atmaja \& Aliamin, 2015). Nugroho, et al (2012) memberikan hasil riset yang berbeda bahwa belanja modal mempunyai pengaruh negatif signifikan terhadap kinerja keuangan pemerintah daerah.

$\mathrm{H}_{4}$ : diduga belanja modal berpengaruh signifikan terhadap kinerja finansial di Pemerintah Daerah Kabupaten Karanganyar.

Beberapa hasil penelitian terdahulu belum konsisten. Penulis tertarik menggali berbagai faktor pengaruh kinerja finansial pemerintah daerah. Hal itu dapat bermanfaat sebagai sarana evaluasi dan antisipasi.

\section{METODE PENELITIAN}

Penelitian kuantitatif ini mengkaji, menganalisis, dan mendeskripsikan kinerja finansial pemerintah daerah Kabupaten Karanganyar. Data penelitian dikumpulkan menggunakan teknik purposive sampling. Sampel penelitian berupa laporan keuangan Pemerintah Daerah Kabupaten Karanganyar selama 8 (delapan) periode tahun 2010-2017, dan dilakukan analisis statistik deskriptif, serta regresi linear berganda terhadapnya.

Variabel terikat berupa kinerja finansial Pemerintah Daerah Kabupaten Karanganyar (Y). Variabel bebasnya berupa ukuran $\left(\mathrm{X}_{1}\right)$, kekayaan $\left(\mathrm{X}_{2}\right)$, leverage $\left(\mathrm{X}_{3}\right)$, dan belanja modal $\left(\mathrm{X}_{4}\right)$. Ukuran pemerintah daerah diwakili total aset. Kekayaan diproksikan dengan PAD. Leverage didefinisikan oleh hutang total dibanding seluruh ekuitas. Belanja modal adalah total belanja pemerintah daerah seperti alat, permesinan, bangunan, sarpras, dan berbagai aktiva tetap lain.

Kerangka konsep penelitian ini digambarkan sebagai berikut:

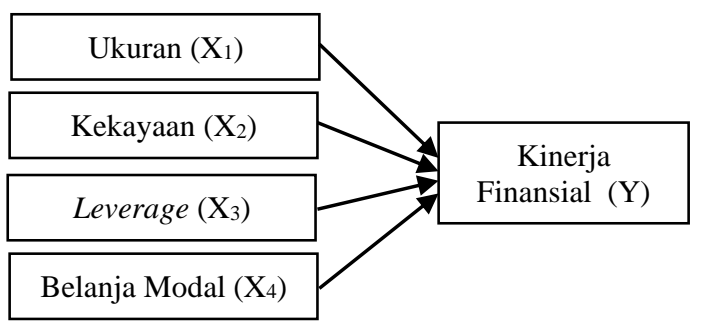

Gambar 1. Kerangka Penelitian

Keterangan:

$\longrightarrow$ menunjukkan pengaruh variabel bebas (ukuran, kekayaan, leverage, dan belanja modal) terhadap variabel terikat (kinerja finansial Pemerintah Daerah Kabupaten Karanganyar).

\section{HASIL PENELITIAN}

Hasil penelitian sebagai berikut:

TABEL 1. Hasil Statistik Deskriptif

\begin{tabular}{lrlllr}
\hline \multicolumn{7}{c}{ Descriptive Statistics } & \\
\hline & $\mathrm{N}$ & Min & \multicolumn{1}{c}{ Max } & Mean & $\begin{array}{c}\text { Std. } \\
\text { Deviation }\end{array}$ \\
\hline Ukuran $\left(\mathrm{X}_{1}\right)$ & 8 & 26.35 & 28.54 & 27.9302 & .84738 \\
\hline Kekayaan $\left(\mathrm{X}_{2}\right)$ & 8 & 25.22 & 26.67 & 25.9066 & .45177 \\
\hline Leverage $\left(\mathrm{X}_{3}\right)$ & 8 & .00 & .01 & .0033 & .00183 \\
\hline
\end{tabular}




\begin{tabular}{lcccccc}
\hline \hline Belanja Modal $\left(\mathrm{X}_{4}\right)$ & 8 & 25.50 & 27.69 & 26.4510 & .81628 \\
\hline Kinerja Finansial (Y) & 8 & .01 & .08 & .0376 & .02316 \\
\hline Valid N (listwise) & 8 & & & & \\
\hline Sumber: Hasil Olah Data, 2019
\end{tabular}

Sumber: Hasil Olah Data, 2019

TABEL 2. Hasil Regresi Linear Berganda

\begin{tabular}{|c|c|c|c|c|c|}
\hline \multirow[b]{3}{*}{ Model } & \multicolumn{3}{|c|}{ Coefficients $^{\mathrm{a}}$} & \multirow[b]{3}{*}{$\mathrm{t}$} & \multirow[b]{3}{*}{ Sig. } \\
\hline & \multicolumn{2}{|c|}{$\begin{array}{l}\text { Unstandardized } \\
\text { Coefficients }\end{array}$} & \multirow{2}{*}{$\begin{array}{c}\begin{array}{c}\text { Standardized } \\
\text { Coefficients }\end{array} \\
\text { Beta }\end{array}$} & & \\
\hline & B & Std. Error & & & \\
\hline 1 (Constant) & -75.792 & 28.951 & & -2.618 & .047 \\
\hline Ukuran $\left(\mathrm{X}_{1}\right)$ & 109.039 & 33.216 & .873 & 3.283 & .022 \\
\hline Kekayaan $\left(\mathrm{X}_{2}\right)$ & 3.754 & .926 & 1.907 & 4.054 & .010 \\
\hline Leverage $\left(\mathrm{X}_{3}\right)$ & -.582 & .779 & -.180 & -.747 & .489 \\
\hline $\begin{array}{l}\text { Belanja Modal } \\
\left(\mathrm{X}_{4}\right)\end{array}$ & -.231 & .325 & -.167 & -.710 & .510 \\
\hline
\end{tabular}

\section{PEMBAHASAN}

Uji hipotesis membuktikan bahwa: ukuran memiliki pengaruh positif signifikan terhadap kinerja finansial Pemerintah Daerah Kabupaten Karanganyar. Uji t secara parsial menunjukkan nilai positif yaitu thitung sebesar 3,283 dan signifikansi 0,022. Hal ini mendukung penelitian Sari (2016) dan menerima hipotesis pertama.

Kekayaan mempunyai pengaruh positif signifikan pada kinerja finansial Pemerintah Daerah Kabupaten Karanganyar, ditunjukkan dari nilai t hitung 4,054 dan signifikansi 0,010 . Penelitian ini mendukung riset Sari (2016) dan Leki, et al. (2018) serta mendukung hipotesis kedua.

Leverage berpengaruh negatif tidak signifikan terhadap kinerja finansial Pemerintah Daerah Kabupaten Karanganyar, berdasarkan nilai negatif uji $\mathrm{t}$ yaitu $\mathrm{t}_{\text {hitung }}$ sebesar -0,747 dengan signifikansi 0,489 yang lebih besar dari nilai taraf signifikansi 5\%. Ini menolak hasil penelitian Perwitasari, 2010; Minarsih, 2015; dan Sari, 2016 serta menolak hipotesis ketiga.

Uji t menunjukkan bahwa pengaruh belanja modal adalah negatif tidak signifikan terhadap kinerja finansial Pemerintah Daerah Kabupaten Karanganyar sebesar -0,710, dengan signifikansi 0,510. Hasil penelitian sejalan dengan penelitian Nugroho, et al (2012). Persamaan regresi linear berganda menyajikan model kinerja finansial
Pemerintah Daerah Kabupaten Karanganyar adalah $\mathrm{Y}=-75,79+109,039 \mathrm{X}_{1}+3,754 \mathrm{X}_{2}-$ $0,582 \mathrm{X}_{3}-0,231 \mathrm{X}_{4}$.

\section{KESIMPULAN}

Hasil penelitian menunjukkan bahwa ukuran pemerintah daerah memiliki pengaruh positif signifikan, kekayaan berpengaruh positif signifikan, leverage mempunyai pengaruh negatif tidak signifikan, dan belanja modal berpengaruh negatif tidak signifikan terhadap kinerja finansial Pemerintah Daerah Kabupaten Karanganyar. Makna yang didapat adalah semakin besar ukuran dan kekayaan dianggap mampu meningkatkan kinerja finansial, sedangkan makin tinggi leverage dan belanja modal justru menurunkan kinerja finansial. Model kinerja finansial Pemerintah Daerah Kabupaten Karanganyar $\mathrm{Y}=-75,79+$ $109,039 X_{1}+3,754 X_{2}-0,582 X_{3}-0,231 X_{4}$.

\section{DAFTAR PUSTAKA}

Andirfa, M., Basri, H., \& Majid, M.S. (2016). Pengaruh Belanja Modal, Dana Perimbangan dan Pendapatan Asli terhadap Kinerja Keuangan Kabupaten dan Kota di Provinsi Aceh. Jurnal Magister Akuntansi. Pascasarjana Universitas Syiah Kuala Banda Aceh, 5(3), 30-38.

Atmaja, R. \& Aliamin. (2015). Pengaruh Kekayaan Daerah, Dana Perimbangan dan Belanja Daerah terhadap Kinerja Keuangan (Studi pada Kabupaten/ Kota di Aceh). Jurnal Perspektif Ekonomi Darussalam. 3(2), 168-181.

Febrianto, N. (2018). Pengaruh Ukuran Pemerintah Daerah, Pendapatan Asli Daerah (PAD), Belanja Modal, Ukuran Legislatif, dan Intergovernmental Revenue terhadap Kinerja Keuangan Pemerintah Daerah (Studi Empiris pada Kabupaten dan Kota di Propinsi D.I.Y Tahun 2009-2016). Skripsi Dipublikasikan. Universitas Muhammadiyah Surakarta.

Fitriani, N. L. P., \& Dwirandra, A. A. N. B. (2014). Penilaian Kinerja Keuangan 
Daerah Kabupaten/ Kota di Provinsi

Bali Tahun 2007-2011. E-Jurnal Akuntansi Universitas Udayana. 8(1), 211-227.

Ghozali, I. (2011). Aplikasi Analisis Multivariate Dengan Program SPSS. Semarang: Badan Penerbit Universitas Diponegoro.

Halim, A. (2016). Akuntansi Sektor Publik: Akuntansi Keuangan Daerah. Jakarta: Salemba Empat.

Halim, A. \& Abdullah, S. (2015). Hubungan dan Masalah Keagenan di Pemerintah Daerah: Sebuah Peluang Penelitian Anggaran dan Akuntansi. Jurnal Akuntansi Pemerintahan, 2(1), 53-64.

Hananto, A. Y. (2017). Pengaruh Ukuran Pemerintah Daerah, Intergovernmental Revenue, dan Belanja Daerah terhadap Kinerja Keuangan Pemerintah Daerah (Studi Kasus pada Pemerintah Daerah Kabupaten/ Kota di Pulau Jawa). Skripsi dipublikasikan. Universitas Sebelas Maret Surakarta.

Hasan, Y. (2013). Kemampuan Keuangan Daerah pada Otonomi Daerah (Kajian dalam Manajemen Publik). Al Munir, 2(IV), 94-109.

Leki, Y., Amran T., Naukoko, \& Sumual, J. (2018). Pengaruh Pendapatan Asli Daerah dan Belanja Modal terhadap Kinerja Keuangan pada Pemerintah Kabupaten Halmahera Barat. Jurnal Berkala Ilmiah Efisiensi, 18(05), 164-174.

Lo, A. W; Orr H. A, \& Zhang R. (2017). The Growth of Relative Wealth and The Kelly Criterion. SSRN No. 2900509. September 2017.

Mardiasmo. (2016). Akuntansi Sektor Publik. Yogyakarta: Penerbit Andi.

Minarsih, R. A. (2015). Pengaruh Size, Wealth, Leverage, dan Intergovernmental Revenue terhadap Kinerja Keuangan Pemerintah Daerah di Jawa Tengah. Skripsi. Universitas Negeri Semarang.
Mulyani, S \& Wibowo, H. (2017). Pengaruh Belanja Modal, Ukuran Pemerintah Daerah, Intergovernmental Revenue dan Pendapatan Asli Daerah terhadap Kinerja Keuangan (Kabupaten/ Kota di Propinsi Jawa Tengah tahun 20122015). KOMPARTEMEN: Jurnal Ilmiah Akuntansi, XV(1), 57-66.

Nugroho, F. \& Rohman, A. (2012). Pengaruh Belanja Modal terhadap Pertumbuhan Kinerja Keuangan Daerah dengan Pendapatan Asli Daerah sebagai Variabel Intervening (Studi Kasus di Propinsi Jawa Tengah). Diponegoro Journal of Accounting, 1(2), 1-14.

Perwitasari, C. (2010). The Influence of Financial Performance to The Level of Accountability Disclosure of Indonesia's Local Government. Tesis. Fakultas Ekonomi Universitas Sebelas Maret Surakarta.

Puspitasari, A. F. (2013). Analisis Kinerja Keuangan Pemerintah Daerah Kota Malang Tahun Anggaran 2007-2011. Skripsi. Fakultas Ekonomi dan Bisnis Universitas Brawijaya Malang.

Sari, I. P. (2016). Pengaruh Ukuran Pemerintah Daerah, PAD, Leverage, Dana Perimbangan dan Ukuran Legislatif terhadap Kinerja Keuangan Pemerintah Daerah (Studi pada Kab/ Kota Pulau Sumatera). JOM Fekon, 3(1), 679-692.

Sari, N. M. D. P \& Mustanda, I. K. (2019). Pengaruh Ukuran Pemerintah Daerah, Pendapatan Asli Daerah, dan Belanja Modal terhadap Kinerja Keuangan Pemerintah Daerah. E-Jurnal Manajemen, 8(8), 4759-4787.

Sijabat, M. Y., Saleh, C., \& Wachid, A. (2014). Analisis Kinerja Keuangan serta Kemampuan Keuangan Pemerintah Daerah dalam Pelaksanaan Otonomi Daerah (Studi pada Dinas Pendapatan Daerah dan Badan Pengelola Keuangan dan Aset Daerah Kota Malang Tahun Anggaran 2008-2012). Jurnal Administrasi Publik, 2(2), 236-242. 
Syamsuddin, L. (2016). Manajemen

Keuangan Perusahaan: Konsep

Aplikasi dalam: Perencanaan,

Pengawasan, dan Pengambilan

Keputusan (Edisi Baru). Jakarta: Raja

Grafindo Persada.

Turley, G., Robbins, G., \& McNena, S. (2015). A Framework to Measure The Financial Performance of Local Governments. Local Government Studies Journal, 41(3), 401-420.

UU No. 23/2014 tentang Pemerintahan Daerah 